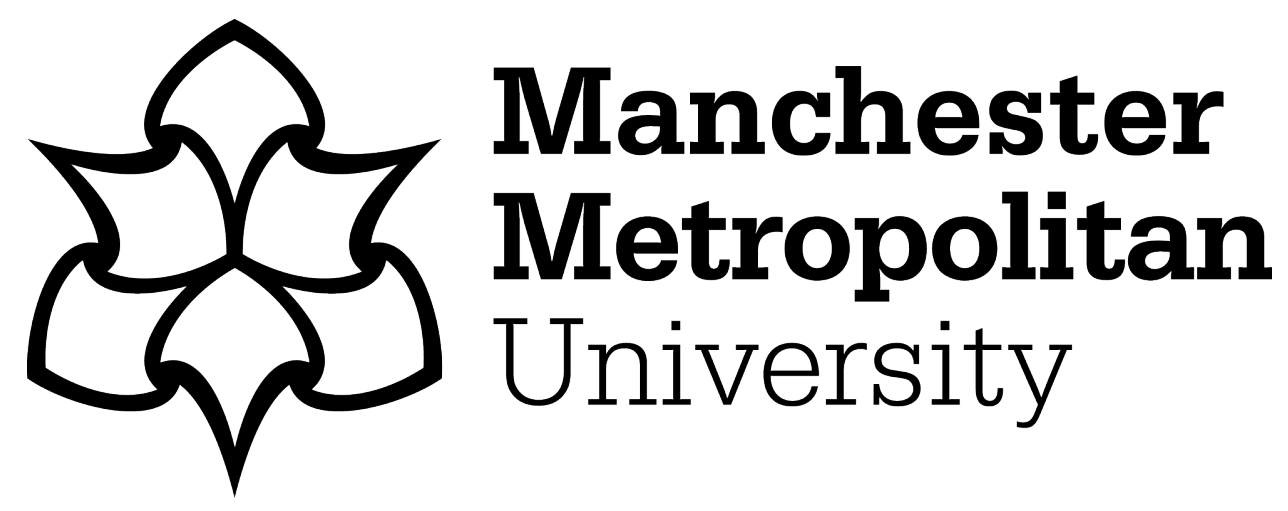

Edensor, T and Kothari, $U$ (2018) Consuming colonial imaginaries and forging postcolonial networks: on the road with Indian travellers in the 1950s. Mobilities, 13 (5). pp. 702-716. ISSN 1745-0101

Downloaded from: https://e-space.mmu.ac.uk/621638/

Version: Accepted Version

Publisher: Taylor \& Francis

DOI: https://doi.org/10.1080/17450101.2018.1476020

Please cite the published version 


\title{
Consuming colonial imaginaries and forging postcolonial networks: on the road with Indian travellers in the 1950s
}

\author{
Tim Edensor and Uma Kothari
}

\author{
Tim Edensor \\ School of Science and the Environment \\ John Dalton Building \\ Manchester Metropolitan University \\ Oxford Road, Manchester M15 6BH \\ t.edensor@mmu.ac.uk \\ Uma Kothari \\ Global Development Institute \\ University of Manchester \\ Oxford Road, Manchester M13 9PL \\ Uma.kothari@manchester.ac.uk
}

\begin{abstract}
Drawing on an extended road trip from England to India undertaken by two Indian travellers in the 1950s, this paper challenges the dominant travel stories and Eurocentric academic accounts that persistently privilege western tourists. Focusing upon the literary desires that shaped their British itinerary and a dramatic encounter in Egypt, we highlight two distinctly different experiences that emerged during their journey. We demonstrate how a swirl of larger historical events and processes marked the time in which they travelled, with the encounters, places and incidents they experienced informed by the dissipation of colonial alliances and the emergence of postcolonial connections.
\end{abstract}

\section{Introduction}

In their late 20 s and recently married, Shanti and Tara decided to go on the holiday of a lifetime. On June 5 , 1955, they arrived at Southampton, England on a passenger ship from Bombay, India, purchased a car and spent the next six months motoring overland back to India on a modest budget of $£ 6$ per day. After a few weeks in London, they spent a month journeying around the UK and then extended their adventure by traveling to Europe, passing through many countries including France, Austria, Switzerland and Italy. They strolled through the streets of Paris, and the cities of Belgium, the Netherlands and Denmark. Remarkably, they arrived in Vienna on the day of Austrian Independence, 27 July 1955 and were greeted with hugs by Austrians who exclaimed that they too, were now free, free from the post-war shackles of the Allied Powers, as India had freed itself from British colonial rule in 1947. They lingered in the Swiss Alps, visited the salt mines of Austria, and travelled to the renaissance cities of Northern Italy. After two months in Europe, they took the boat from Genoa to Alexandria in Egypt. They then took their car on a ship down the Suez Canal to Aden carrying on their journey visiting numerous other places in Africa before selling the car in Kenya and boarding a ship back to India. Due to their status as commonwealth citizens they rarely required visas to cross national borders.

Their trip took place at a significant geo-political moment. Colonised nations were struggling for independence as colonial powers adapted to the rapid contraction of their empires. For Tara and Shanti, the arrival of Indian Independence in 1947 produced an epochal postcolonial moment in which exciting possibilities for travel adventures arose. While their journey was certainly exceptional in these post-war years, in earlier colonial times travellers from non-western realms were far from unusual. Yet, these travellers are almost entirely absent from historical accounts of tourism. Many academic accounts continue to evoke a geographical 
imaginary of a dynamic, proactive, primarily Western core that contrasts with a parochial Third World periphery, a dichotomy that suggests that those from the west travel while others are sedentary, anchored in place. This is echoed in both the extraordinarily Western-oriented preoccupations of popular travel writing and Eurocentric academic accounts of travel and tourism, despite the recent surge in tourism from non-Western countries.

By focusing on the extended journey undertaken by two Indian tourists in the 1950s, this paper challenges the universalising, over-general theories of tourism that persist. In so doing, we emphasise the culturally and historically specific contexts that influence all tourist motivations and fantasies. Here we highlight how the journey of Shanti and Tara was shaped by two particular historical processes that conditioned their expectations, experiences and encounters. First, the scenic, cultural and historical attractions to which they were drawn - especially in the UK - were powerfully conjured up by the imaginaries in which they had been enmeshed as colonial subjects prior to Indian independence. For their enduring familiarity with representations and discourses about Britain that swirled through education, media and conversation in pre-Independence India informed the composition of their itineraries. Secondly, and in contrast, the mid-1950s was also a postcolonial era, characterized by emergent networks through which non-western travellers encountered people from other newly independent nations, shared historical and cultural references, swapped memories of anti-colonial struggles and discussed politics. This paper thus also demonstrates how non-western travel accounts can challenge bounded distinctions made between colonial and postcolonial imaginaries by revealing how they are interwoven and suffused with ambiguities and contradictions.

Tara and Shanti are the parents of X, one of the authors of this paper. Tara was born in Ahmedabad in the Indian State of Gujarat in a lower middle-class family. Her father was active in the independence movement and though keen for her to be involved, stressed the importance of education. She attended a local Gujaratimedium school and went on to study for a BSc in Microbiology in the English-medium St Xavier's College in Bombay. Shanti was born and attended school in a small provincial town in Gujarat until he too went to college in Bombay to study Business and Accounting. While his father had made a fortune from cotton production in the 1930s, he lost it with the industry's decline. The now rather impoverished family attempted to maintain their middle-class lifestyle. In undertaking their trip, Shanti took six months leave from his job as a clerk in the Bank of India while Tara, who had accepted a job as a school teacher, negotiated to commence this post on their return. Their families were unable to loan them much, so they borrowed enough money from Shanti's friends and colleagues to pay their passage on the steamer to England and allow for a limited travel budget.

Various forms of oral evidence have become increasingly important in shaping contemporary writing about the past, chiming growing scholarship that deals with 'marginalia - the unarchived or uncatalogued' (Dwyer and Davies, 2010). Oral history raises challenging questions about historical verification and the reliability of memory. In these living memories individuals implicitly interpret the past by what they omit and include, and which incidents and experiences they emphasise. This reveals that 'memory is not a passive depository of facts, but an active process of creating meanings' (Portelli 1991, 51). As Tara said recently, 'I remember pieces by pieces, I don't remember the whole journey. The pieces I remember are love pieces. We stood side by side on a bridge or a hill looking around us. Just sharing the view. We were in love'. Rosy anecdotes and romantic recollections dominated the retelling of their travels. Upsetting events were also recalled, but were generally retold humorously and as if they were less significant. Prominent here is an encounter with racist abuse that they experienced in Oxford in which their romantic views of the river and the 'dreaming spires' were rudely disrupted. Though for most of their journey through Britain they had met little hostility, their travel experience was tainted by the leering expressions, crude gestures and racist catcalls of a group of youths on a punt passing under the bridge on which they were standing. Shanti recalls, "Tara was very anxious and I said to her, 'why are you so upset, do you understand what they are saying?', and she shook her head and so I said, 'well then since you don't understand what exactly they are shouting let's just turn to face them, and smile and wave. We must have looked very silly!" While retold with humour, this unpleasant incident was repeatedly recounted, testifying to its emotional impact. Thus, while optimistically seeking beauty and civility, they retained a measure of critical reflexivity, as discussed further below. 
Although certain episodes had become polished with repetition, the narratives of their journey changed shape over time, highlighting how personal stories are rarely related consistently. Early accounts justified their choice of holidaying destinations when their children were young. For example, Shanti explained when embarking on their third family holiday to Switzerland, 'mum and I loved Switzerland, we had a wonderful time there and met such good people. When we stayed in a chalet on the hill the farmer came one morning and left a basket of fruits outside our door. Bringing us a gift! That kindness brings tears to my eyes even now'. He further opined that Italy was to be avoided since 'when we were on our trip, we only purchased one souvenir, a beautiful tea set, but we were robbed in Naples and lost everything'. Subsequently, when in their 80 s, their stories were shaped more by romance and delight in all that they had encountered, with unpleasant incidents shrugged off, with Tara explaining 'some people are not so nice but why should we remember those things'. As with other life stories, these travel narratives were inevitably located in wider social contexts, in relationship, meanings, languages and national cultures. As such, some of their stories were retold in the context of wider contemporaneous influences. For example, the 1970s expulsion of Ugandan Asians and the current refugee crisis made them reflect on the ease of movement that they had enjoyed in the 1950s with their Commonwealth passports. Their stories further reveal much about the relationship between the tellers and listeners. Shanti always referred to one of the authors of this paper, his middle daughter, as 'the family archivist', the one who engaged them in recollections and continuously asked questions. Additionally, while their interpretations of events were mediated by which of them was telling the story, this was largely a joint recollection.

The difficulties of creating biographical portraits from fragments have been well documented (McGeachan et al., 2012). There are certainly gaps and absences in Tara and Shanti's story but as White writes, this does not matter as we are 'building something from the remains', and there are parallels with how archives are characterised by incompleteness, fragmentation and partiality. We acknowledge the cracks and slippages in their tale and how with temporal distance and advancing age they became increasing inclined to remember the delights of their travels. Yet, the multiple fragments and different versions collected over time enable us to piece together an account of their journey.

Rather than pursuing a more conventional account that derives its authenticity from a handful of illustrative interview quotes, we develop a story-telling mode that benefits from the longevity and intimacy of our own situated relations with Shanti and Tara. Over many years, they have regularly recounted anecdotes of their extraordinary journey at family gatherings, or when an incident, person or object sparked a memory. Although we have taped and transcribed certain stories, the anecdote also serves as a valuable research device (Michael, 2012), with our listening providing us with a privileged, intimate form of knowing that would not be generated through a more standard interview approach. These stories were given greater substance and structure with the discovery a few years ago of their travelogue, two old school exercise books found in a locked briefcase in a cupboard in their house in India. Each page was divided into four columns that detailed date, places 'left' and 'reached', miles travelled and quantity of petrol remaining in the tank. Their financial accounts also provided rich details of the cost of food and accommodation, the places they stayed and their spending choices. As Shanti was the sole driver, these books were penned in Tara's handwriting, written while journeying in the car. Our account is thus a bricolage that weaves together these different forms of data.

The paper is divided into three sections. First, we critically review tourism and travel literature and academic theories, showing how these are blighted by an unreflexive, universalising Eurocentrism, and then highlight how recent accounts attempt to address these deficiencies and feature non-Western tourisms. Second, we discuss the colonial imaginaries that shaped the itineraries devised by Tara and Shanti, showing how powerful literary and cinematic influences directed their desires to visit particular British locations and informed their mode of travel. Third, we detail a salient encounter in Egypt that testified to the historical emergence of postindependence connections, anti-colonial politics and shared cultural references out of which new postcolonial networks emerged. 
The overwhelming focus on the western traveler in academic and travel accounts reminds us that one of the integral contexts for the emergence of modern tourism emerged out of the colonial project and from the power relations, representations of otherness and opportunities for travel that it promoted. With adventure, exploration and travel primarily conceived of as a Euro-American privilege during the colonial era, the status of the 'traveller' and the embryonic figure of the tourist was predominantly assigned to those who embarked on voyages motivated by educational, scientific and recreational imperatives. In capturing the public imagination, travel accounts depicted early European explorers as 'heroic'. Subsequently, 'empire' tourism emerged, organised to cater to desires to visit destinations made newly accessible through colonial conquest and administration, including trips organized by Thomas Cook, initiated in 1869, to see the antiquities of Egypt, and subsequent safaris to East Africa. As Mackenzie points out, colonial ventures were legitimized not just through 'war, economic exploitation ... settlement, and...cultural diffusion' but by engendering 'empires of travel' (2005: 19). Through such infrastructures, tourists could experience the sites written about by adventurers, traders and missionaries who had fuelled the production of specific imaginaries. Colonial tourism further expanded as railway journeys, roads, maps and guidebooks were developed, and a hospitality sector grew to include a servant class employed to cater to tourist needs and desires. Yet colonial travel remained a privilege, associated with 'gendered, racial bodies, class privilege, specific means of conveyance, beaten paths, agents, frontiers, documents and the like' (Clifford 1997: 38-39). Unhindered mobility became the hallmark of the usually male Western traveller.

Despite assumptions that foregrounded the European tourist, travel across and between colonial realms was multi-directional and varied in purpose. Yet non-European travel remains invisible apart from in those historical accounts that focus on forcibly removed colonised people: transported slaves and convicts, indentured labourers and exiled anti-colonial political 'undesirables' (Kothari 2012). In challenging Eurocentric assumptions about who travelled, Pirie shows how 'the growth of tourism occurred amid a complicated matrix of transnational forces' (2015: 4) in specific historical contexts (Zuelow 2011), including travel between various colonial settings. These claims are supplemented by other accounts: Hazbun (2015) explores how Arab and Muslim visitors viewed British-ruled Cairo, and Edwards and Graulund (2011) foreground how the world was also mapped out by non-European travellers. A focus upon such non-European travellers allows us to identify the alternative forms of knowledge that they produced, subverting the Eurocentrism of travel narratives.

These travel stories also emerge following colonialism and further decentre conceptions of tourism as European practice, as exemplified by our story of Tara and Shanti, two middle class, postcolonial Indian tourists. Even though the British Empire lingers on in contemporary travel stories and theoretical construals of 'the tourist', through our account we demonstrate that postcolonial travel narratives can 'resist the gravitational pull of metropolitan centrality' (Edwards and Graulund, 2011: 2). Our postcolonial journey also shows that while colonial forms of tourism reinforced inequalities between people and places, a key impulse behind tourist development was the gradual democratization of travel. For instance, the Grand Tour was once the provenance of a British and northern European elite but subsequently became available to the middle-class masses (Towner 1985). Postcolonial tourists were also involved in this 'democratising impulse of tourism' (Baranowski et al 2015).

Reductive historical understandings are also echoed in contemporary studies that overwhelmingly focus on non-western travellers who move to Europe and North America, not as tourists but as migrants, emigrants, exiles, domestic servants and refugees, travel for trade, business or education, or are part of an extended diaspora. Such mobilities, it is inferred, denote an involuntary displacement wherein travellers lack agency and express little desire for exploration, adventure and self-development, unlike the ever-curious, adventurous western tourist. By contrast only limited scholarship focuses on those postcolonial tourists who travel independently, like Tara and Shanti.

The dearth of available non-Western tourist accounts is matched in academic study where contemporary theories of tourism are based on a cluster of paradigmatic assumptions. In tourist studies, tourism is primarily 
conceived as a modern phenomenon that was born in the West and only subsequently spread to the rest of the world. Relatedly, geographic flows of international tourism are understood as originating from developed Western countries and towards the undeveloped 'pleasure periphery' (Turner and Ash 1975), construing a unidirectional 'North-to-South' or 'West-to-East' movement (Winter 2009: 23) in which Western 'international tourists' are received by their 'hosts' in the destinations to which they travel (Mkono 2011). Strikingly, these dualistic accounts also ignore the crucial role of colonialism in the emergence of modern tourism, and its influence on contemporary representations, practices and spaces. Instead, they focus upon the emergence of European sensibilities grounded in the 'Grand Tour'. This underplays how many tourist representations continue to portray non-western destinations as 'exotic', 'timeless', more 'natural', pre-modern sites of 'simple living', and the ways in which highly managed enclaves allow tourists to separate themselves from the 'others' in their midst (Edensor 2001).

These normative assumptions about the historical emergence of tourism and its contemporary manifestations are compounded by the Eurocentric, over general and functional theories that account for the underlying development of tourism per se. In declaring that all contemporary tourists are impelled by particular motivations and carry out specific practices, such influential theories disregarded tourism's multiplicity. For instance, it has been asserted that tourists enter a realm of liminality or discover an authenticity absent from their own societies (McCannell 1978). While the more salient account by Urry (1990) that foregrounds diverse forms of tourist gaze opens up the potential for exploring how different tourists consume destinations, the suggestion remains that a key motivation is to gaze romantically upon an 'exotic' 'Other'. Recent studies of independent travellers remain similarly oriented towards a Western perspective (Loker-Murphy and Pearce 1995), with typical motivations identified as the desire to seek novelty, escape routine, acquire cultural capital, develop the self and search for 'authenticity' (Maoz 2007; Riley, 1998; Paris and Teye 2010).

These Eurocentric theories have failed to acknowledge the specific cultural contexts from which they emerge, and as Towner (1995: 340) points out that '[s]o far, all we have studied is a western model of tourism evolution, not how it has varied in different cultures and different times'. He calls for a shift from paradigmatic assumptions about a single Western origin to a recognition of the plurality of tourisms in diverse localities and at various times. Hazbun (2009: 205) similarly argues that the view that tourism developed in England and thenceforth diffused over the world 'ignores other possible points of origin'. The result has been, as Alneng remarks a 'relative indifference towards, and sometimes complete denial of, non-Western tourism' (2002: 137).

In responding to these critiques, recent approaches have attempted to expand understandings about tourist motivations and practices, and diverse studies of non-western tourists are increasing in number. Accounts of contemporary non-western travel and tourism include Muzaini's (2006) exploration of Asian travellers in southeast Asia, and Teo and Leong's (2006) analysis of the independent travel landscapes experienced by Japanese, Korean, Malaysian and Singaporean travellers in Thailand. Maoz (2007: 136) acknowledges the 'differences amongst back-packers from different countries in their perception of freedom, escapism, and moratorium, in their travel motivations, as well as in their interactions with other tourists, an assertion underpinned by Ong and du Cros's (2012) examination of the experiences of Chinese backpackers to Macau. Winter et al (2008) direct attention to diverse forms of Asian travel, Mkono (2011) considers the varied practices of African tourists and Hazbun (2015) details the cultural origins of the distinctive beach tourism practised by Moroccans. In similarly confounding conventional assumptions about the motivations of nonwestern travellers, in accounting for their desire to embark on their journey, Tara and Shanti often expressed irritation, cursorily exclaiming, 'Why not? Why shouldn't we want to see the world?' Shanti also recounted a particular incident: 'We were in Austria and wanted to cross into Hungary. The soldier at the border asked us "Why do you want to come to Hungary? What is the purpose of your visit?" I said, "Excuse me sir, I am sorry but I don't understand your question". The man shouted at us, repeating "why do you want to come to Hungary". We looked at each other and then back at the guard and I said, "because we want an adventure"'. The idea of seeking an adventure defined their reason for travelling. 
Below, we detail aspects of their account, focusing upon the distinctive historical conditions under which their tour was carried out. First, we foreground the literary and cinematic influences that informed the imaginaries that inspired their trip, and shaped the organisation, preconceptions and experiences of their tour.

\section{Travelling imaginaries: postcolonial literary tourism and modern motoring}

Much critical scholarly writing has focused on the construction of an imaginary that legitimized colonial rule through perpetrating various distinctions between coloniser and colonised. As Said (1989: 218) writes, 'we would not have had empire itself... without important philosophical and imaginative processes at work in the production as well as the acquisition, subordination, and settlement of space'. A British colonial imaginary typically constructed the 'other' through discursive hierarchical distinctions between people, with colonised people characteristically defined as backward, incapable of self-government and culturally inferior. Colonial administrators, teachers, soldiers and civil servants also enacted forms of Englishness in producing a distinctive identity and social distance. As Nash claims, 'white English class and gender identities were constituted through colonial relationships and interconnections' (2004:117), showing the imbrication of expressions of Englishness with its apparent other. Comparisons that articulated the 'virtues' of Englishness were integral to the reproduction of imaginary geographies of an idealised 'home' (Gowan, 2002), in contradistinction to subordinate colonised spaces.

As Salazar (2011: 863) writes, 'it is hard to imagine tourism without the creative use of seductive as well as restrictive imaginaries about peoples and places'. The substantial colonial literature written by European travellers is replete with stereotypical, classificatory assertions that reiterate privileged knowledge. Tour agents, travel brochures and magazines continue to propagate 'exotic' images of non-Western destinations that resonate with these earlier colonial representations (Palmer 1994) perpetrating reified ideas about otherness. However, discussions about tourist representations almost entirely focus on the production of those imaginaries that promote travel to non-western destinations. However, imaginary baggage can also be carried by those who travel from the non-West to the West as part of what Pratt (2008) calls 'transculturation', the process by which subordinate groups make use of materials from metropolitan cultures. Critically, in addition to producing knowledge about the colonised realm (Chakrabarty 2000), colonialists also influenced the knowledge that those they colonised had about Britain, its people, landscapes, history and culture. Following decolonisation, such understandings persisted, as temporally and 'spatially extended transactions' that connected people, ideas and practices (Lester 2006) and they were subsequently reworked in the postindependence period.

Shanti and Tara's desire to travel to Britain and Europe, their mode of travel and their itineraries were greatly influenced by knowledge acquired during life under British colonial rule. They learned about Britain through the romantic images of landscapes and historic places that adorned the picture calendars that hung in their homes and schools. This imaginary was also fostered by teachers, both British and Indian, and by the books they read that conjured up a mythical Britain of castles, country estates, seaside towns, prehistoric monuments, castles, venerable seats of learning and ecclesiastical traditions. And above all, they felt compelled to visit places chronicled in literary works (Reijnders 2011). For Tara and Shanti, those places fuelled by colonial imagination and desire that once seemed a world away, could now be visited without stringent barriers to their movement; they arrived in Britain with hyperreal expectations of what they would see and the people they would meet.

Shanti and Tara's visit coincided with accelerating national tourist promotion and hotel sector development to attract greater numbers of foreign tourists to the UK. To help organize their journey, they purchased the popular, rather hyperbolic guide book published by the British Travel and Holiday Association, Britain, A Book Which Attempts To Do More Than Its Size Permits (1952). Immediately, the book whetted their appetite to travel in claiming 'a country which by reason of its structure, position and history has, perhaps, more beauty, interest and variety to offer the visitor than any other country in the world' (ibid: 7). In Britain, according to 
Buzard (2001: 312), the UK is represented as 'the veritable home of the touristic sublime', and 'a land so teeming with sights valuable to tourists that it beggars representation'. In being saturated with such detail, the nation is construed as place 'so packed with significance that a step in any direction sets of historical and affective resonance'.

Informed by the guidebook, Tara and Shanti visited many of the iconic sites that had filled their imagination during their education, places that had seemed magical and tinctured with romance. Thus, 'we already knew about all the places we wanted to see' and so they wandered around London, visiting the Tower of London, Buckingham Palace, Houses of Parliament, Westminster Abbey and Trafalgar Square. Tara admired the architecture although was disillusioned with Buckingham Palace, which she described as a rather 'ugly, grey building', and Trafalgar Square, full of 'frightening and dirty pigeons'. Yet she enjoyed window shopping and lingering in London's parks, and she experienced a freedom impossible in Indian streets at a time where scrutiny of women in public space was often overbearing: 'I felt so free walking around with no one watching everything you did. And I felt free with Shanti too, we could for the first time be affectionate in public'. Shanti, who had an abiding love of cricket, an enthusiasm that extended to following the exploits of the England team captained by Len Hutton, made a pilgrimage to Lord's Cricket Ground which he admitted 'was smaller than he had expected it to be'. Besides these iconic London attractions that they had read so much about, they were eager to visit Oxford and Cambridge renown centres of British educational excellence. When in Oxford, Tara recalled, 'We were standing by a wall, with us on one side and Oxford University on the other. Can you believe we were in Oxford? Two ordinary people from India, here at the great Oxford University'. Their disbelief at actually seeing the University in real life was compounded by their visit to Cambridge where while having a picnic on the lawns of a college they exclaimed 'how can they allow us to do this. No one asked us to move and didn't ask what we were doing there'. They also felt compelled to experience some of the scenic landscapes, seaside resorts and historic attractions that featured in so many of the British representations that infused their school years. They drove through the Lake District and Scottish Highlands, dallied at Great Yarmouth and Brighton, explored the castles at Windsor, Inverary and Edinburgh, and visited the ancient sites at Stonehenge, Bath and Kilmartin.

Yet the key focus of the trip around Britain were the symbolic sites associated with English literature; they were literary tourists (Robinson and Andersen, 2004). This was stimulated by Shanti and Tara's deep familiarity with many of the iconic poets, playwrights and novelists whom they learned of through the English literature taught during their school education under colonialism. This literary influence clearly resonates with the effects intended by the architect of Colonial Britain's Educational Policy in India, Thomas Macaulay, who in 1835 , declared, 'we must do our best to form a class... of persons Indian in blood and colour, but English in taste, in opinions, words and intellect' (Hall, 2008). In extolling the benefits of this policy, in 1846 Macaulay offered a toast, 'To the literature of Britain ... which has exercised an influence wider than that of our commerce and mightier than that of our arms' (Whitehead 2005). English literature thus became an integral part of the education of many Indians, though in 1921, day-to-day administration was devolved to provincial governments who assumed formal responsibility for most aspects of education policy. This led to the introduction of Sanskrit and Hindi texts in many secondary schools, subjects enthusiastically explored by Shanti and Tara, but the study of English literature also largely persisted. In the postcolonial era, English literature has continued to influence Indian cultural life, but not necessarily as an enduring legacy of cultural imperialism, for as Trivedi remarks (1995: 1), rather than considering English literature as an imposition on colonial India, it is better conceived as a 'transaction', a complex, changing and adaptive 'interactive, two-way dialogic process' rather than an 'active-passive' exchange. Similarly, the regard that Shanti and Tara had for the literary figures that they so admired was not simply oriented around their Britishness but was grounded in the ambiguity and mutability of their works. These included works by Kipling and Hardy, E. M. Forster's A Passage to India and John Masters' Bhowani Junction, as well as the less renowned Edward Thompson, whose Indian trilogy expressed sympathy with the nationalist movement.

It was Lord Byron and Walter Scott, however, that stood out as their biggest literary heroes. This inspired Tara and Shanti to make pilgrimages to Edinburgh's Scott Monument and Byron's home at Newstead Abbey in 
Nottinghamshire, Though now out of fashion, historical novelist and poet Scott was hugely popular in British India, and along with a 'vast reading public across the English-speaking world' (Rigney, 2012: 8), both Shanti and Tara had read Waverley, Ivanhoe and Rob Roy and Shanti was fond of reciting extracts from his lengthy poems, The Lady of the Lake and Marmion. According to Rigney (ibid), Scott's novels and poems formed a 'common point of reference 'within the multinational and transnational framework of Great Britain and the Empire' through the creation of a shared 'secular pantheon of imaginary and historical figures'. Indeed, Rigney avers that though it generated potent notions of Scottishness, Scott's fiction 'was not tied to any one place or community', was translatable to local, national and transnational contexts while contributing to the 'Anglophone cultural sphere' (ibid: 11-12).

At Newstead, the imaginaries stoked by Bryon's poems were further stimulated by the scenic surroundings of the ruined medieval Abbey, the grandeur of the venerable house and the fantastic landscape of the estate, with its 300-acre woodland, formal garden designs, sweeping lawns, lake and waterfalls (Busby and Shetliffe, 2013). Features of the estate inspired his Elegy on Newstead Abbey and Don Juan, as well as Epitaph to a Dog, inscribed on the memorial to his dog at Newstead. Besides these pleasures, Shanti and Tara also found the desk at which Byron wrote and his letters, paintings, books and other personal belongings evocative; indeed, a visit to these quarters was fuelled by the guidebook's description of 'the ancient and ancestral home of the poet Lord Byron, whose bedroom and sitting room are kept in the state in which he left them (1952: 77). Poetry, personal effects and site melded to produce a powerful tourist experience. Yet crucially, though an icon of Englishness, Byron's romantic and anti- British imperialist poetry had succoured the visions of those campaigning for Indian independence, and though orientalist, offers a sympathetic rendering of the East. Thus, although Byron's poetry had been an essential ingredient in their colonial education, and epitomised the transmission of hierarchical educational values, their meanings could not be confined by the educational contexts in which they were taught, and Shanti and Tara's interpretations were aligned with their anti-colonial sentiments. Their families had been fiercely anti-colonial and Tara in particular, influenced by her father's political activism, had been enthusiastically involved in the Independence movement, alongside her student friends.

Most auspiciously of all, on 30 June 1955, Tara and Shanti paid nine shillings at the Shakespeare Memorial Theatre, in Stratford upon Avon, to see a performance of Macbeth starring Vivien Leigh and Laurence Olivier. Although Shanti said, 'I couldn't really understand the words, what they were saying, they were speaking so fast and with such funny voices', they were ecstatic to have watched a Shakespeare play at Stratford. Like many Indian schoolchildren, they had learned several of Shakespeare's plays, works that had been 'imperialistically projected as the very flagship of English culture' (Trivedi, 1995: 2). Yet their consumption of the bard's plays extended beyond the classroom. For in addition to their association with the plays of Shakespeare, Leigh and Olivier were global Hollywood icons with whom the two tourists were very familiar. Leigh had starred in the hugely popular Gone with the Wind, the most successful film in box office history (if changing rates of inflation are accounted for). Olivier was inextricably linked with Shakespeare's plays, and awarded the Oscar for best picture for his 1948 British film adaptation of Hamlet, in which he starred and directed, a director-actor role he also undertook in Henry V (1944 and Richard III (1955). Gone with the Wind and the Shakespeare productions were popular with Indian cinema-goers and Tara and Shanti had enjoyed these films during their college days visiting many of the numerous popular cinemas in Bombay to watch both English-speaking and Bollywood films. The latter were also becoming increasingly popular and influential in countries of Indian immigration in 'East Africa, Mauritius, the Middle East and South-East Asia, but also in a significant swathe of Northern Africa' from the 1950s (Vasudevan 1995: 306).

Despite the colonial presumptions of cultural superiority that initiated the introduction of Shakespeare to school curricula across India, Shakespeare's works became and remain immensely popular amongst educated, English-speaking Indians. Indeed, the influence of this Shakespearian legacy persists, with adaptations and themes drawn from the bard's works continuing to resound through contemporary Bollywood productions (Yadav, 2014) following the 1954 Hindi movie version of Hamlet (directed by Kishore Sahu) that adhered closely to the Olivier production, despite the inclusion of songs. As with Byron and other literary classics of 
English literature, Indian versions of Shakespeare's works, whether in English or translated into diverse languages, have been adapted to address distinctively Indian issues and contemporary politics. Similarly, for Tara and Shanti, these multi-interpretable works were entangled in expressions of nationalism, colonialism and postcolonialism.

These entanglements with colonial influences are also evident in the mode of travel that they chose, an automobile tour, a form of travel that had particularly developed in post-war Britain, with touring motorists taking to the roads in increasing numbers in search of nature, regional peculiarities and history. British middleclass tourists were now able to drive further afield as cars became more affordable, and likewise, the car journey - and guide book - facilitated Tara and Shanti's quest to experience Britain as two tourists. Their desire to motor through Britain and Europe was fuelled by the association of car travel with the British in India (as well as the Indian elite). When working as a junior clerk in a British-run bank, Shanti had admired the cars of his employers and was enchanted by their accounts of long drives to the hills in the summer months. He said, "I saw the manager one day leaving work and getting into his car. It was filled with big hampers and he would shout out to us 'I'm heading to the hills". It looked like so much fun'. This colonial imaginary extended into the choice of vehicle: they purchased a second-hand classic Morris Minor, an iconic car that signified post war British modernity and the advent of more widespread motoring. Moreover, Shanti and Tara were already somewhat familiar with this car since Hindustan Motors of India modelled the Ambassador, produced in the early 1950s, the most abundant automobile on India's roads, on the Morris cars. Tara and Shanti spent over four months in their second-hand vehicle, motoring British style. They joined the English 'middle classes, comfortably and safely located in their Morris Minor' (Urry, 2000: 26) and could imagine that like them, they were undertaking 'a kind of voyage through the life and history of the land'. They made use of maps and travellers' organisations in London that had primarily been devised for western motorists and joined the Automobile Association and the British Travel and Holidays Association (BTHA).

Like many tourists, Shanti and Tara embarked on their journey with pre-existing images, envisaging that it would sustain the idealised representations that had infused their childhoods that Britain represented a more civilised, cultured, orderly and even, glorious world. Yet this was always in danger of being revealed for the myth that it was, deflated by particular incidents and unexpected observations. The illusion that the British were invariably polite and 'civilised' was disrupted and the highly developed, modern country that they had learned about was accompanied by less savoury aspects. Like many other non-western tourists to Britain, they felt disheartened by the greyness and the cold. Tara had been compelled to purchase a coat, even though they had arrived in Britain in May, and she was aware that this bright red garment made her stand out even more as 'foreign' against the dull clothing of those around her. On occasion, their disappointment turned into outright criticism, something previously unimaginable. Due to their limited budget, they had to stay in 2-star hotels but were surprised to find themselves in less than clean accommodation at which they had to share a bathroom with other guests. More profoundly disorienting was their witnessing of poverty. The Britain that had been presented to them as rich and civilised, capable of ruling impoverished and inferior colonies, was disavowed by the poorly-dressed and seemingly malnourished figures that crowded London's streets.

The esteemed literary sites, historical locations and scenic landscapes that they visited on their journey around the UK were inspired by desires stoked during their colonial education. Yet though these literary influences certainly conjured up images and ideas that epitomised Britishness, they also transcended these intimations, stirring postcolonial and global connections. Accordingly, their tourist imaginaries were not immutable, singular and fixed but were reworked along their journey. As we now discuss, these travel experiences were crucially also augmented by other encounters, distinctively new postcolonial connections forged after they left Britain. We now explore these very different encounters by focusing upon a key incident that they experienced in Egypt.

\section{Making Postcolonial Connections}


On 17 September 1955, Shanti and Tara arrived at Alexandria, Egypt, walking down the gangway of the Lloyd Triestino, a passenger ship that they boarded in Naples. They waited for their Morris Minor that had travelled with them to be delivered on the quayside and then drove towards Cairo. They were excited to be in Egypt, a country that had, like India, been colonised by the British and had successfully fought for independence. In 1955, Egypt's president Gamal Abdel Nasser and India's Prime Minister Jawaharlal Nehru became the founders of the Non-Aligned Movement, evidencing a long-standing affiliation and friendship between the two countries. Tara and Shanti thus arrived in Egypt at a significant political juncture. Although in 1922 Britain had declared limited independence for Egypt, it was not until the 1952 revolution that the country finally wrested itself from British influence, and when they arrived, as British troops were withdrawing, the country was in the process of establishing itself as an independent state.

Early on 25th September 1955, Tara and Shanti began their 200-kilometre drive from Cairo to Port Said, intending to board a cargo ship that would voyage down the Suez Canal to Aden. Throughout their trip, they often diverged from their planned route to satisfy their curiosity and on this occasion, they broke their journey 120 kilometres from Port Said to visit the city of Ismailia, situated on the west bank of the Suez Canal, and the headquarters of the Canal Authority. On the city's outskirts, they lost their way and suddenly, a roadblock appeared out of the dust. Armed men, Egyptian soldiers, ordered the two tourists to stop. Brandishing their guns, the soldiers' bodies tensed as they surrounded the vehicle and with terse instructions, commanded Tara and Shanti to wind down the windows.

They had accidentally entered a militarized zone adjacent to the Suez Canal. Tensions in Egypt had risen following President Nasser's decision to procure a large arms deal with the Soviet Union, following thwarted attempts to secure a similar arrangement with the USA. The rise of Nasser's pan-Arab nationalism and a desire to play a leading political role in the region, together with the anxieties promoted by pervasive global Cold War conflict and the unravelling of French and British colonial power, had produced a volatile situation. This would eventuate in the notorious 'Suez Crisis' in 1956, culminating in the invasion of Egypt by Israeli forces, and subsequently, British and French bombing campaigns, following Nasser's decision to nationalize the Canal to control access and accrue revenues from passing ships. The episode was a seminal moment that decisively signified the diminishing global role of the UK, whose forces were forced to retreat under overwhelming American political pressure.

As they surrounded the car and peered inside, the hard expressions of the soldiers softened as it became apparent that the travellers posed no threat. They were not dealing with white Europeans. 'Nasser, Tito, Nkrumah, Nehru or Sukarno?', they enquired of Tara and Shanti, reciting the names of the leaders of the NonAligned Movement. Upon hearing the reply, 'Nehru', the soldiers greeted the visitors with broad smiles and responded by pointing to their chests and exclaiming 'Nasser, Nasser'. Like these Egyptians, Tara and Shanti had formerly been subjects of the British Empire, and like them, they had reasserted their independence against the colonial power and were intent on claiming their rights as citizens of an independent nation. The Non-Aligned Movement was born at the Asia-Africa Conference held in Bandung, Indonesia in April 1955, only weeks before the two tourists began their trip, convened to bring together the leaders of 29 states, largely former colonies from Africa and Asia, to discuss common concerns in resisting the pressures of the major global and former colonial powers, maintaining their independence and developing joint policies in international relations. Nehru, the acknowledged senior statesman, led the conference along with Indonesian Prime Minister Sukarno and Nasser, who had led the 1952 Revolution had become Prime Minister in 1955. Crucially, the members of the movement sought to retain neutrality in the face of the growing polarisations being generated by the ominous emergence of the Cold War, and sidestep the looming influence of both the USA and the Soviet bloc.

Once the Indian identity, and importantly, the shared anti-colonial subjectivity of the two tourists had been confirmed, the excitement of the soldiers grew as they noticed Tara's sari. They enthusiastically pronounced upon her likeness to the Indian actress Nadira, who had played a starring role in the 1952 Bollywood movie Aan, which Shanti and Tara had watched together at Bombay's Liberty cinema. After a short burst of 
animated chatter amongst themselves, the soldiers broke out into a lusty rendition of one of the songs from the film, 'Main Rani Hoon Raja Ki', their upright bearing transformed as their boot clad feet shifted in accompanying approximations of Bollywood dance moves. Shanti and Tara joined in the singing; they had seen the film when it was released and could remember all the words and tunes from the soundtrack sung by Mohammed Rafi and Lata Mangeshkar. Aan had also been recently released in Egypt. With its melodramatic and romantic storyline, fabulous scenery, energetic choreography and memorable melodies, Aan was watched by millions. Produced for the striking sum of 3.5 million rupees, the movie easily recouped the layout, grossing 15 million. It was Bollywood's first feature in Technicolor, included several major stars and was one of the first Indian films to have a worldwide release. In Egypt, it proved enormously popular. From this time, Hindi movies became highly regarded in Egypt until the 1980s, when protectionist measures implemented by the Ministry of Culture to safeguard the sustainability of the local film industry curtailed their distribution. After their musical interlude, the soldiers laid down their guns and recommended the safest route out of Ismailia before bidding Tara and Shanti a fond farewell.

Tara and Shanti departed, relieved but exhilarated by their encounter. This was more than a fleeting moment of affinity forged through the Non-Aligned Movement, anti-British nationalism or shared enthusiasm for an Indian film. The incident had a profound and lasting impact on them. They had been witnesses at a site where imperialism was being dismantled and independence asserted. The significance of the encounter was amplified once they returned to India and recounted it to their friends. This compounded their abiding respect for the Non-Aligned Movement. The two tourists had been caught in the midst of a local crisis that was entangled with wider global connections and postcolonial strategic interests, and informed by a nascent imaginary stoked by the emergent popular culture of Bollywood films in Egypt. Thus, they had arrived in Egypt at a key political moment, entering a national space that was being encompassed by new political and cultural networks. This reveals that though Castells maintains that 'networks constitute the new morphology of our societies' (1996: 469), networks have long existed in different forms, densities and extent prior to recent times.

We have demonstrated above how colonial networks were productive of particular imaginaries. Moreover, reified colonial binaries can be challenged by disclosing 'the integrative nature of ...cultural traffic, the ways imperial institutions and structures connected disparate points in space into a complex mesh of networks' (Ballantyne 2002: 39). For colonial relations were always stretched in contingent and non-deterministic ways, across space, and did not necessarily privilege either metropolitan or colonised spaces. Rather they remade both metropolitan and colonial places in the process of connecting them. A network approach, according to McKenzie (2005: 3), thus 'recasts the relationship between metropolitan centre and colonial periphery into a more contested, unstable and mutually constitutive frame'. This is aptly exemplified by the ambiguous ways in which Tara and Shanti experienced the sites they visited in Britain, as well as the shifting meanings of the literary and cinematic works that inspired these visits.

Crucially, in the post-war spaces across which Tara and Shanti travelled, new, distinctively postcolonial networks were emerging. Tara and Shanti's Egyptian encounters catalysed connections that were emerging prior to their arrival. They were made resonant by shared historical contexts wherein both India and Egypt had experienced British colonial rule and successful national independence struggles. In addition to avoid becoming entangled in either Soviet and American strategies, postcolonial desires to maintain recently acquired political independence was also integral to the formation of the Non-Aligned Movement. Nasser's decision to nationalise the Suez Canal was received with sympathy by the two tourists, and symbolized how they and the soldiers shared a subaltern positionality that they endeavoured to transcend. Cultural connections were forged by shared enjoyment of a highly popular Bollywood film, prefiguring the later global expansion of media, film and television networks including the global dissemination of Bollywood cinema (Gopal 2008).

These emerging, globally constituted postcolonial networks connected distinct parts of the world in different ways, and served to refashion place and identity (Featherstone et al 2007). In focusing on how the particular political and cultural networks discussed here incorporated and were simultaneously co-produced by two non- 
western travellers in the 1950s, we further challenge privileged western narratives of travel and disavow notions that certain tourist destinations are 'timeless' and 'traditional', exotic locations in which western tourists may vicariously experience the past.

This focus on networks also aligns with the emergence of new thinking about mobilities (Hannam et al. 2006), and resonates with earlier global flows of people, money, commodities, information and knowledge. While the ability to become mobile is hugely unequal, there is a danger that in acknowledging these iniquitous powergeometries, there is a tendency to assume that the western subject - and in the context discussed here, the western tourist - is hypermobile, while others continue to be moored in place, unable to travel. Cohen and Cohen recognize that on the contrary, a mobilities approach can demolish such unreflexive assumptions, for it 'does not distinguish between a centre and periphery of tourist activity; it does not assume a single point of dissemination of tourism; and it does not prioritize a particular kind of motivation for tourism' (2015: 14). This supports our contention that tourism has never been essentially Western and that non-western forms of tourism have been neglected. As a consequence, the global connections and networks reproduced through non-western mobile practices have also been ignored.

As Cohen and Cohen further contend, a mobilities approach also fosters a shift 'from a synchronic to a diachronic perspective, involving a change of emphasis from permanence to flux, from being to doing, from structure to agency, from sedimented social patterns to the process of their emergence and from a focus on the more stable fixtures of social life to the mobilities linking them' (2012: 2180). This highlighting of emergence and flux foregrounds how through their travels, Shanti and Tara participated in the ongoing making of postcolonial connections that bypassed established tourist routes and nodes. The fresh tourist adventures that became available for Indians and others following national independence allowed them to sidestep the previously constrained prospects for travel to the west, opening up possibilities to forge new relationships and mobile experiences.

\section{Conclusion}

As we have emphasised, academic discussion of tourism and travel accounts have almost exclusively focused upon the preoccupations, routes and habits of European and Anglo-American travellers. Rare indeed are accounts of non-western travellers, especially from the post war period. We have focused on one very particular journey undertaken in the 1950s, when admittedly, Indian tourists to Europe would have been unusual, in order to highlight the absence of such stories. These numerous accounts and the particular preoccupations, normative practices, itineraries and discourses that they articulate have formed the empirical basis from which extraordinarily Eurocentric theories and concepts about tourism have derived. We use Shanti and Tara's account to critically interrogate the over-general theoretical assertions that are largely based on what some tourists from certain cultural locations do at other particular places some of the time. Here, we insist that scholarly explorations of tourism must always focus on the specific historical, cultural and political conditions under which tourists travel, and widen their enquiries to include a much broader range of tourist identities, routes and spaces.

As Lisle (2006) maintains, travel writers and tourists alike are invariably entangled within extended relationships and connections, amidst the swirl of larger events and processes that condition their travel routes, generate the kinds of encounters and experiences they have, and shape their own concerns and interests. Like all tourists, Shanti and Tara were informed by their own preoccupations and desires that shaped their journey, influenced both by colonialism and by India's anti-colonial struggles. They were drawn to the UK as the 'mother country', the centre of empire, and their imaginaries were greatly stimulated by their shared respect for English and Scottish poetry and literature. But very different attachments were also emerging at the time of their journey, associations forged through shared experiences of decolonisation, independence and the emergence of postcolonial identities that connected Shanti and Tara to the Egyptian soldiers they 
encountered. Their travel experiences testify to an era in which new, distinctive global connections were emerging while others were diminishing.

In foregrounding the particular travel experiences of Tara and Shanti, we also join those who demand that histories and stories of non-western people urgently need to be communicated to put those that masquerade as normative into perspective. We endorse Chakrabarty's (2000) claim that we need to 'provincialize Europe' by problematizing, deconstructing and decentring the mooted universality of Western knowledge, in our case by challenging the continuing legacy of western accounts that dominate scholarship on travel and tourism. An uncovering of previously unrepresented narratives is essential to identify how those who were formerly colonised oppose the processes through which they were defined and confined (Said, 1978). We thus highlight the integral role of colonialism in generating tourist imaginaries of elsewhere - here through an imaginary of Britishness forged in colonial India - and post war tourist experiences that testify to new, emergent connections and imaginaries that challenge dominant depictions.

We have emphasized that the emergence of modern tourism is thoroughly entangled with colonialism, and continues to resonate in a host of non-Western destinations. Despite this, colonialism is hugely neglected in the influential, overarching accounts that have characterized its conceptualisation. Yet as we have demonstrated, tourism may also be productive of other, divergent imaginaries and connections that transcend these colonial contexts. Crucially though, these should be considered neither as mere exotic variants of a preexisting, originary European modern process nor separate effects within a relativist scenario of multiple modernities. Rather, as Bhambra (2010) insists, these emerge from diverse interconnected histories, including histories of colonialism. This underlines that in conceptualising contemporary and historical expressions of tourism, studies must recognise the mutually constitutive global events, processes and developments that affect both western and non-western places and people, and persistently produce an interconnected world.

\section{References}

Alneng, Victor. 2002. "The modern does not cater for natives: travel ethnography and the conventions of form." Tourist Studies 2 (2): 119-142.

Ballantyne, Tony. 2002. "Empire, knowledge and culture: from proto-globalization to modern globalization: In Globalization in World History, edited by Anthony Hopkins, 115-40. London: Wiley.

Baranowski, Shelley, Christopher Endy, Waleed Hazbun, Stephanie Malia Hom, Gordon Pirie, Trevor Simmons, and Eric Zuelow. 2015. "Tourism and empire." Journal of Tourism History 7 (1-2): 100-130.

Bhambra, Gurminder. 2010. "Historical sociology, international relations and connected histories." Cambridge Review of International Affairs 23 (1): 127-143.

British Travel and Holidays Association. 1952. Britain, A book which attempts to do more than its size permits. London: The British Travel and Holidays Association.

Burton, Anionette. 1998. At the Heart of Empire: Indians and the Colonial Encounter in Late-Victorian Britain. Berkeley: University of California Press.

Busby, G. and Shetliffe, E. 2013. "Literary tourism in context: Byron and Newstead Abbey." European Journal of Tourism, Hospitality and Recreation 4 (3): 5-45. 
Buzard, J. 2001. 'Culture for export: Tourism and autoethnography in Postwar Britain', in S. Baranowski and E. Furlough eds. Being Elsewhere: Tourism, Consumer Culture and Identity in Modern Europe and North America, Ann Arbor: University of Michigan Press, pp 299-319

Cameron, E. 2012. "New geographies of story and storytelling." Progress in Human Geography 36 (5), 573592.

Castells, Manuel. 1996. The Rise of the Network Society: The Information Age: Economy, Society and Culture. Oxford: Blackwell.

Chakrabarty, Dipesh. 2000. Provincializing Europe: Postcolonial Thought and Historical Difference. Princeton, $\mathrm{NJ}$ : Princeton University Press.

Clifford, James. 1997. Routes: Travel and Translation in the Late Twentieth Century. Cambridge: Harvard University Press.

Cohen, Erik, and Scott Cohen. 2012. "Current sociological theories and issues in tourism." Annals of Tourism Research 39 (4): 2177-2202.

Cohen, E. and S.A Cohen. 2015. A mobilities approach to tourism from emerging world regions. Current Issues in Tourism, 18 (1): 11-43.

Edensor, T. 2001. "Performing tourism, staging tourism: (Re)producing tourist space and practice". Tourist Studies 1 (1): 59-81.

Edwards, Justin, and Rune Graulund, eds. 2010. Postcolonial Travel Writing: Critical Explorations. New York: Springer.

Featherstone, David, Richard Phillips, and Johanna Waters. 2007. "Introduction: spatialities of transnational networks." Global Networks 7 (4): 383-391.

Gopal, Sangita, and Sujata Moorti, eds. 2008. Global Bollywood: Travels of Hindi song and dance. Minneapolis: Minnesota University Press.

Gowan, G. 2002. "A Passage from India: geographies and experiences of repatriation, 1858-1939." Social and Cultural Geography 3 (4): 403-323.

Hall, C. 2008. Making colonial subjects: education in the age of empire. History of Education, 37 (6): 773-787.

Hannam, Kevin, Mimi Sheller, and John Urry. 2006. "Editorial: Mobilities, immobilities and moorings." Mobilities $1(1): 1-22$.

Hazbun, Waleed. 2009. "Modernity on the beach: A postcolonial reading from southern shores." Tourist Studies 9 (3): 203-222.

Hazbun Waleed. 2015. "The folds of place", In Rami Isaac, Colin Michael Hall, and Freya Higgins-Desbiolles eds The Politics and Power of Tourism in Palestine, 166-177. London: Routledge

Kothari, U. 2012. "Contesting colonial rule: politics of exile in the Indian Ocean." Geoforum 43 (4): 697-706.

Lester, Alan. 2006. "Colonial networks, Australian humanitarianism and the history wars." Geographical Research 44 (3): 229-241. 
Lisle, Deborah. 2006. The Global Politics of Contemporary Travel Writing. Cambridge: Cambridge University Press.

Loker-Murphy, Laurie, and Philip L. Pearce. 1995. "Young budget travelers: Backpackers in Australia." Annals of tourism research 22 (4): 819-843.

MacCannell, Dean. 1989. The Tourist. A New Theory of the Leisure Class. Berkeley: University of California Press.

MacKenzie, John. 2005. "Empires of travel: British guide books and cultural imperialism in the 19th and 20th centuries". In John Walton ed, Histories of Tourism: Representation, Identity and Conflict, 19-38. Bristol: Channel View.

Maoz, Darya. 2007. "Backpackers' motivations the role of culture and nationality." Annals of tourism research 34 (1): $122-140$.

McGeachan, C, I. Forsyth, and W. Hasty. 2012. "Certain subjects? Working with biography and life-writing in historical geography." Historical Geography 40: 169-185.

Michael, Mike (2012) 'Anecdote', in C. Lury and N. Wakeford (eds.) Inventive methods: The happening of the social. London: Routledge. 25-35.

Mkono, Muchazondida. 2011. "African as tourist." Tourism Analysis 16 (6: 709-713.

Muzaini, Hamzah. 2006. "Backpacking Southeast Asia: strategies of "looking local"." Annals of Tourism Research 33 (1): 144-161.

Nash, C. 2004. Postcolonial geographies: spatial narratives of inequality and interconnection. In P. Cloke ed. Envisioning Human Geographies, pp.104-127.

Ong, Chin-Ee, and Hilary du Cros. 2012. "The post-Mao gazes: Chinese backpackers in Macau." Annals of Tourism Research 39 (2): 735-754.

Palmer, Catherine A. 1994. "Tourism and colonialism: The experience of the Bahamas." Annals of tourism Research 21 (4): 792-811.

Paris, Cody and Victor Teye. 2010. "Backpacker motivations: A travel career approach." Journal of Hospitality Marketing \& Management 19 (3): 244-259.

Pirie, Gordon. 2013. "Automobile organizations driving tourism in pre-independence Africa." Journal of Tourism History 5 (1): 73-91.

Pratt, Mary. 2008. Imperial Eyes: Travel Writing and Transculturation. London: Routledge.

Reijnders, Stijn. 2011. Places of the Imagination: Media, Tourism, Culture. Ashgate: Farnham.

Rigney, A. 2012. The afterlives of Walter Scott: Memory on the move. Oxford University Press

Riley, Roger, Dwayne Baker, and Carlton Van Doren. 1998. "Movie induced tourism." Annals of tourism research 25 (4): 919-935. 
Robinson, M. and Andersen, H. eds. 2004. Literature and Tourism, London: Continuum.

Said, Edward. 1978. Orientalism. New York: Pantheon.

Salazar, Noel. 2011. "The power of imagination in transnational mobilities." Identities 18 (6): 576-598.

Teo, Peggy, and Sandra Leong. 2006. "A postcolonial analysis of backpacking." Annals of Tourism Research 33 (1): 109-131.

Towner, J. 1985. The Grand Tour: A key Phase in the History of Tourism. Annals of Tourism Research 12: 297-333.

Towner, J. 1995. "What is tourism's history?" Tourism management 16 (5): 339-343.

Trivedi, H., 1995. Colonial transactions: English literature and India. Manchester: Manchester University Press.

Turner, Louise and John Ash. 1975. 'The Golden Hordes': International Tourism and the Pleasure Periphery. London: Constable.

Urry, John. 1990. The Tourist Gaze. Leisure and Travel in Contemporary Societies. London: Sage.

Urry, John. 2000. Sociology Beyond Societies. London: Routledge.

Vasudevan, R. 1995. "Addressing the spectator of a 'third world' national cinema: the Bombay social film of the 1940s and 50s." Screen 36 (4): 305-324.

White, T. 2004. "Theodore and Brina: an exploration of the myths and secrets of family life, 18511998." Journal of Historical Geography 30: 520-530.

Whitehead, C. 2005. "The historiography of British imperial education policy, Part I: India." History of Education 34 (3): 315-329.

Winter, Tim, Peggy Teo and T. C. Chang eds. 2008. Asia on Tour: Exploring the Rise of Asian Tourism. London: Routledge.

Winter, T. 2009. "Asian tourism and the retreat of anglo-western centrism in tourism theory." Current Issues in Tourism 12 (1): 21-31.

Yadav, M. 2014. "Domesticating Shakespeare - A study of Indian adaptation of Shakespeare in popular culture." European Journal of English Language and Literature Studies 2 (3): 48-58.

Zuelow, Eric ed. 2011. Touring Beyond the Nation: a Transnational Approach to European Tourism History. Burlington, VT: Ashgate. 